A. U. Veteriner Fakültesi J. Şiruji Kürsüsü Profesörü Dr. B. Öktem

\title{
KEDİ VE KÖPEKLERDE KALÇA ÇIKIKLARI Ve TEDAVISi
}
Dr. H. ANTEPLIOĞLU
Dr. A. Finct
As. E. SAMSAR

\section{Art. coxae'nin anatomik durumu:}

Üst tarafta pelvis kemikleri, alt tarafta Os femóris'in caput'unun teşkil ettiği ekleme kalça eklemi denir. Fossa acetabularis, os ilium, os 1schii ve os pubis'in uzantılarının birleşmesinden meydana gelmiştir. Yapısı kıkırdakseldir, kenarları çepeçevre Labium articularae (glenoidale) denilen tamamlayıcı bir halka ile çevrilmiştir. Bu genişletici eke rağmen adı geçen çukurluk, caput femoris'i tamamiyle kucaklıyamaz. Caput femoris hemen hemen os femoris'in epifiz'ine dik açı teşkil edecek şekilde yer almıştır. Burada mafsalın yüzü geniş, yarım küre şeklindedir.

Pelvis ile os femoris arasındaki artiküler bağlantıyı husule getiren kısımlar (bağlantılar) şunlardır:

(1) Capsula articularis,

(2) Lig. capitis femoris (Teres femoris),

(3) Lig. accessorium,

(4) Lig. transversum acctabulum.

Kalça eklemi, flexion, extention, adduction, rotation, circumduction (pandülvarî) hareketler yapabilmektedir $(4,11)$.

Hastalığın Tarifi ve Etyologie'si: Hastalık, Art. coxae'yi teşkil eden caput femoris ile fossa acetabularis'in meydana getirdikleri eklemde, bu eklemi teşkil eden kemiklerin anormal bir şckilde ve devamlı olarak birbirinden uzaklaşması keyfiyetidir(2).

Arıza carnivorlarda ve sığırlarda çok görülür, koyun ve keçide daha az, nadiren de tek tırnaklılarda müşahede edilir. Art. coxae'deki dislocation ya tam (complette) veyahutta gayritam (Incomplette) olur. Keza doğmasal (Congenital) olabileceği gibi, sonradan (Aqquise) de olabilir.

Tam olan kalça eklemi luxation'ları, caput femoris'in acetabulum'un muhtelif cihetlerinde bulunduğuna göre aşağı̆daki şekilleri gösterir:

68. 
(a) Anterior veya precotyloid,

(b) Postcrior veya postcotyloid veya Ischiatic,

(c) Intrapelvic veya opturatoral ve

(d) Dışa (lateral) veya suprácotyloid.

Klinik müşahedeler göstermektedir ki, bu arıza genel olarak kırıkla iştirâk etmeksizin şekillenmekte ve bazı vak'alarda kırıkla komplike olmaktadır. İstatistiklere göre; köpek ve kedilerde görülen luxation'ların \% 50 si coxo-femoral eklemde şekillenmektedir. Yukarıda belirtilen dört türlü tam luxation'dan en çok rastlananı Anterior olanıdır sonra fazla rastlanış sırasına göre Posterior ve nadirende intrapelvic olan gelmektedir.

'Carnivor'lar ve sığırda görülen vak'alarda, ençok dikkati çeken husus, luxation'un husule geldiği hayvanlarda Ligamentum pubo-femorale'nin bulunmaması ile ilgili anatomik yapı noksanlığıdır $(6,10)$.

Mafsalın fizyolojik hudutlarını aşan şiddetli hareketlerin tesiri altında husule gelen Art. coxo-femoralis'in luxation'u, os femoris vasitasiyle ekleme nakledilen çekme ve gerilme gibi endirekt tesirler, düşme, dışa kayma, lateral yönden gelen ve ekseriya otomobil çarpmalarına ilgili olan sebeplere bağlıdır. Lateral sadmeler sonu şekillenen luxation'ların çoğunda kırıkta bulunur ve vak'aların çoğunda collum femoris'in kırığına rastlanır.

Kalça eklemindeki luxation ekseriya, bacağın atlama, düşme gibi pozisyonlarda gerilerek, ağırlığın coxo-femoral ekleme lateral yönden geldiği hallerde şekillenmektedir. Lig. teres uzundur ve caput femoris'i acetabulum içinde böyle bir zorlama esnasında zaptedemez. Bundan ayrı olarak capsula articularis te oldukça zayıftır ve basınç altında yırtılır. Caput femoris'in yeri, çarpma sonunda kalça ekleminde husule gelen bükülmenin yönü ile ilgilidir. Bir nakil vasıtası tekerleğinin Art. coxae üzerinden geçmesi de bu arızayı doğuran sebepler arasında zikredilir.

Spontan-olarak şekillenen luxation, arthritis chronica'nın veya arthritis tuberculosa'nın nadiren görülen bir şekli olabilir.

Sığırlarda bilateral art. coxae çıkığı her iki art bacağın dışa kayması halinde görülür. Bu şekildeki çıkıklarda çevredeki kaslarda azçok bir harabiyet husule gelir $(1,2,3,6,-10)$.

Mayer, K.; Lacroix, V. J.;.Hoskins, P. H. (1957), kalça çıkığının congenital predisposition'a bağlı olarảk şekillendiği üzerinde de durmuşlardır. Burada kalça ekleminin fena teşekkülleri zikredilmiştir, acetabulum'un büyük veya küçük oluşu veyahut sathî (yüzlek) oluşu (Coxae plana) collum femoris'in aşağı doğru bükülmüş olarak bulunması (Coxae vera) veya ayrı 
bir femur epifiz'inin bulunması gibi haller burada etüt edilmektedir. Yukarıda adı geçen bozukluklar hayvanın gelişimi esnasında kendilerini belli ederler ve bacaklarda funksiyon bozukluğú (tek veya iki tarafla topallık) ile karakterize olur. Yangının şiddetine ve iskeletteki değişikliğe göre vaziyet gittikçe fenalaşır. Bu olayda rol alan faktörler şunlardır: Trauma, septik yangı, congenital hatalar, endokrin bezlerde funksiyon bozuklukları, beslenme hataları sayılmaktadır.

Yangısel sebeplerle ekseriya caput femoris yassılaşır, düzelir, acetabulum'un çukurluğu genişler ve sathileşir, bugibi hayvanlarda subluxation'lar görülür, şiddetli olanlarda mafsalda dislocation vukua gelir. Congenital olarak subluxation'a mâruz bulunan hayvanların ekserisi, eğer ilgili eklemde bir osteo-arthritis şekillenmezse iyileşirler. Kande'ye göre bu hastalık German Shepherd'lerde, Schnelle'e göre ise arıza daha çok Wire hairred Terrier ve English Setter'lerde görülmektedir (8).

Miller, W. C.; West, G. P. (1959), kalça çıǩı̆ı̆ının bilhassa köpek ırkları arasında pek yaygın bulunduğunu ve bunların birkısmının herediter olduğunu bildirmekte ve bu sonkilcri şu şekilde siralamaktadırlar:

1) Subluxation: Bunda caput femoris bütüı uzunluğunca acétabulum'un içine tetabuk edecek şekilde yerleşmemiştir. Caput femoris'teki deformasyon tedrici bir şekilde olur. Böyle bir arızada hayvan kalkmada zorluk çeker, bacağını bıçkı tarzında hareket cttirir. Bu arıza çoğunlukla 4-5 aylık köpek yavrularında müşahedc edilmektedir (bilhassa Alsatian Irkta bazende Golden Retriver ve Boxer'lerde).

2) Perthe hastalığı: Hafif bir subluxation'la caput femoris'in rarefaction'unu ihtiva eder. Ağrı bazı vak'alarda belirli bir şekildedir. Bu türlü arıza çoğunlukla Pekinges ve Terrier'lerde görülür. Ekseriya sonunda salâha gider veya hayvan 10-12 aylık olduğunda kaybolur.

3) Osteochondritis dissecans: Kisa bacaklı Terrier, Poodle ve Pekingesı ırkında görülür. İkinci paragrafta bildirilen Perthe hastalığından ayırt edilmesi mümkündir: Bu hastalıkta adalî zaafiyet ve topallık ekseriya bir bacakta bulunur.

4) Slipped epiphysis (yerinden kaymıs epifiz): Bu arızada 4-6 aylık köpek yavrularında ağrı ve topallıkla karakterize olur. Fakat Perthe hastalığı ile Osteochondritis dissecans'tan ayırt edilmesi zordur.

5) Congenital dislocation: Bu arızada acetabulum evvelcede bahsedildiği gibi yüzlektir ve caput femoris'i yerinde tutamaz. Arıza Black labrador'larda görülmektedir, zamanla hatalı bir eklem şekillenmesiyle sonuç- 
lanmaktadır(9). Schales (1961), kalça çıkığın, dominant vasıfla geçen kalıtsal bir ıra olarak tarif etmiştir(3).

Pathoiogie'si: Genel olarak arizayla birlikte eklemin capsula's1 yırtılır, anterior olan luxation'da Lig. teres'te kopar ve caput femoris ilium'un corpus kısmının lateral yüzünde yer alır. Situsu cranio-lateraldir ve muhtemelen hafifçe de acetabulum'a nazaran üsttedir (Şekil: 1), Dorsal luxation'da caput femoris acetabulum'un kenarı üzerinde dorsolateral olarak

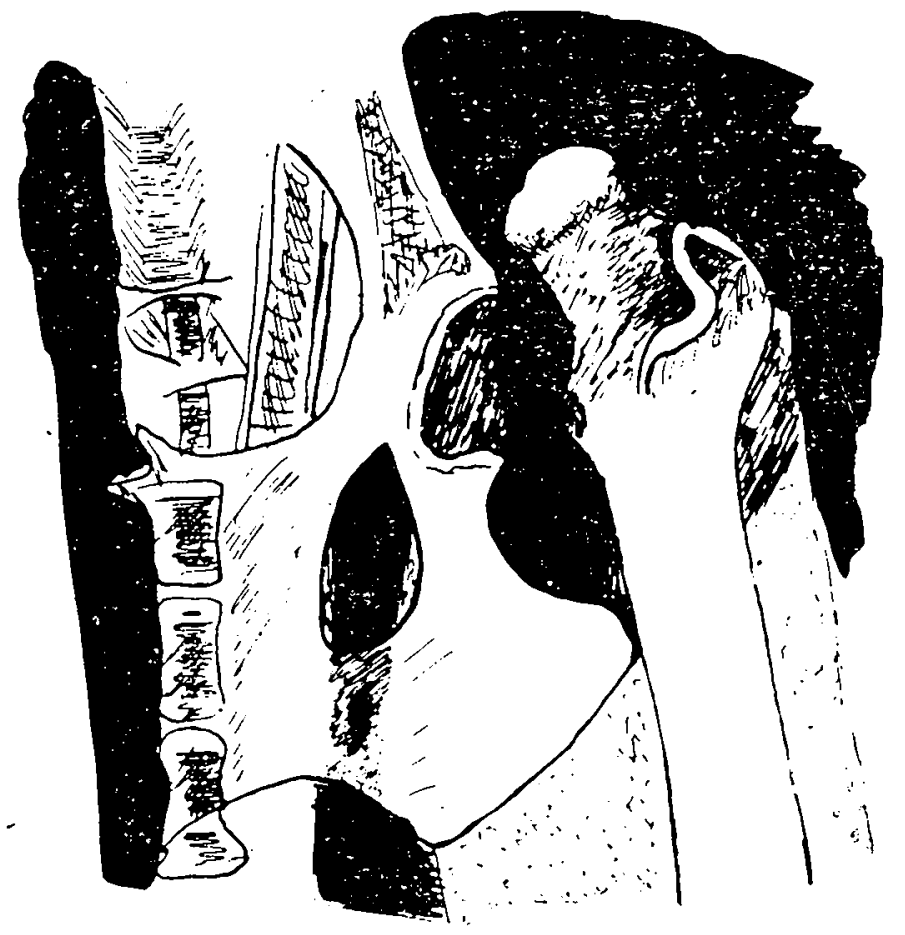

Şekil. 1- Kalça ekleminde anterior precotyloid luxation.

yer alır (Şekil:2). Posterior olan luxation'da ise os ischium'un corpus'u boyunca caudal ve lateral olarak bulunur (Şekil: 3) Civarındaki kaslar zedelenir ve kanamaya sebep oluriar. Anterior luxation'da iliopsoas ve rectus femoris kaslarında fazla bir tahribat şekillenir. Luxation dorsal olduğu vakit, gluteal kaslar, posterior olduğu vakitte quadratus femoris kası zedelenir. Posterior olan luxation'un bazı vak'alarında siyatik sinir tazyik ve trauma sonu paralize olur. Yırtılan kapsula aralıklarından kan eklem boşluğuna dolar, bu kan tedricen fibrinöz bir hale geçer, red ve tespiti geç yapılan vak'alarda güçlük doğurur. Eğer luxation reddedilmezse kapsula 
acetabulum'un üzerini bir perde gibi örterck iyileşir. Caput femoris'te ve acctabulum'da zedelenme bulunur, fakar periarticulaer dokuların fazla miktarda hasara uğramadığı, exostose'un şekillenmediği hallerde ankiloz meydana getirmez. Lukzasyon sonu caput femoris'in necrose'una nadiren rastlanır. Eğer collum femoris'te kırık varsa o zaman vak'ada necrose'da şekillenir $(6,8,12)$.

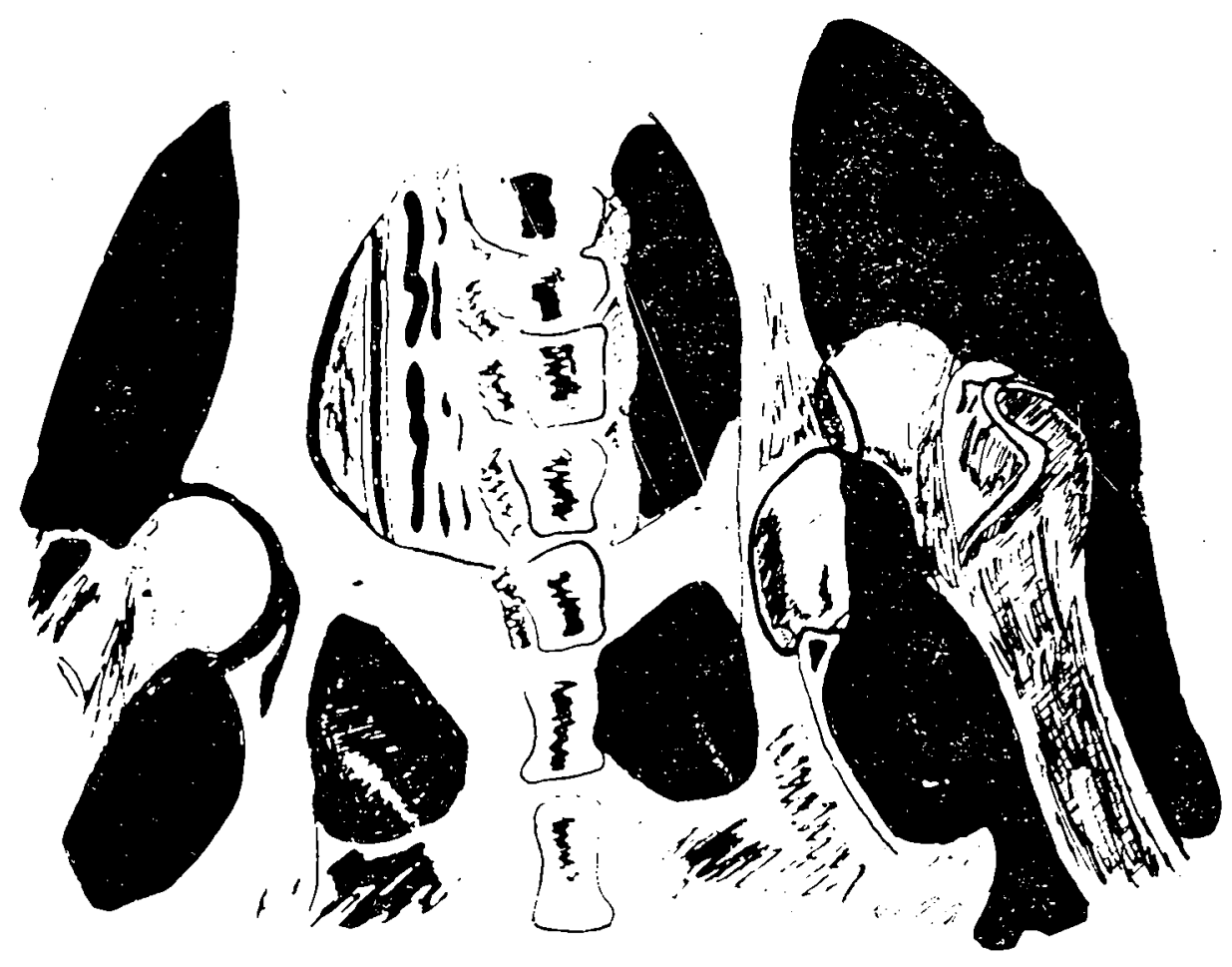

Şekil. 2- Kalça ekleminde dorsal luxation.

Symptome'ları: Eğer mümkinse hasta evvela ayakta muayene edilmelidir. Uzaktan simetrik duruma dikkat edilerek her iki kalça ekleminin arkadan, yandan ve önden yapılacak mukayeseli muayenesiyle symptome'lardan bazılarını tespit etmek mümkindir. Burada Trochanter'in yüksekliği ve bacağın anormal durumu belli bir şekilde görülebilir- Posterior olan luxation hariç diğerlerinde bacak ábduction vaziyetindedir. Kalça anterior luxation'da dışa, posterior luxationda içcri doğru istikamet alır İçeri doğru olan rotation fazla belirgindir, dorsal ve intrapelvic luxatinoda bu vaziyet hafiftir. 


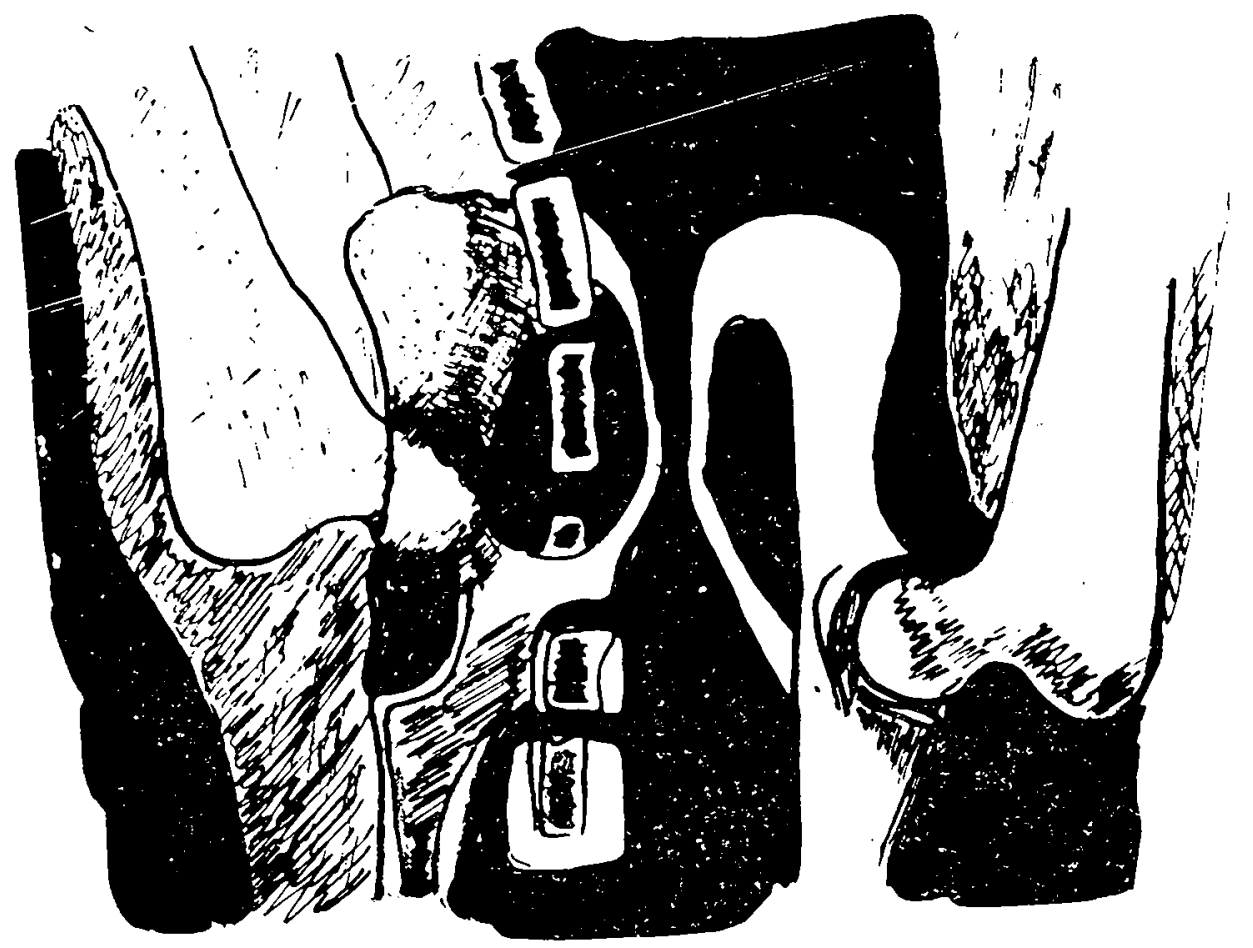

Şekil. 3- Kalça ekleminde posterior (Postcotyloid) luxation.

Hayvan yürürken luxation olan tarafın vücut ağırlığını taşıma keyfiyeti, abductuion veya adduction, içeri veya dışarı rotation halleri dikkate alınmalıdır. Daha fazla bir muayeneye ihtiyaç hissedildiği hallerde hasta anestezi edilerek palpation daha rahatça yapılabilir. Ekseriya kısa tesirli bir barbiturat derivesi ağrı ve kas spazmlarını dindirdiği gibi korku ve çabalamayıda önler. Metodik muayene aşağıdaki şekilde yapılır:

1) Trochanter major palpe edilir, buranın muayenesi ekseriya diagnose'u tam olarak koyabilmek için bir anahtardır. Burada trochanter'in yükselip alçaldığına bakılır. Eğer yükselmişse Tub. coxae'den, Tub; ıschii'ye çekilen hattın üstünde kaldığı görülür. Intrapelvic luxation hariç, diğer bütün luxation'larda yükselme görülür. Ayni zamanda caput ve collum femoris kırıklarında da bu vaziyet müşahede edilir. Keza parçalı pelvis kemiği kırıklariyle, acetabulum'un cranial ve caudal olarak ayrıldığı hallerde de kaybedilir.

2) İkinci olarak trochanter'de rotation olup olmadığına bakılır. Normalde trochanter vücudun uzun eksenine dikaçı yapacak şekildedir. Daima 
mukabil kalça ile mukayese etmelidir. Her iki kalça'dada tub. ıschii'den uzaklığı ayni olmalıdır. Eğer trochanter diğer kalçaya nazaran tub. ıschii'ye yakınsa rotation dışa doğrudur, eğer uzaksa rotation içeri doğrudur. Dişarı olan rotation antcrior olan lux́ation'da, içeri doğru olan rotation'da posterior tip Iuxation'da görülür. Keza trochanter kalça ekleminin sağlam olup olmadığının konrolünde kullanılır. Femur uzun mihveri etrafında hareket ettirilirken bassparmakla Trochanter ile tub. ıschii arası palpe edilir. Sağlam bir eklemde femur döndürülürken trochanter başparmağı sıkıştırır, fakat luxation varsa trochanter parmak üzerine basınç yaptığı vakit geriye kayar.

3) Heriki bacak uzunluğunun muayenẹsi: Hasta sırtüstii yatmış vaziyette yapılır. Tarsal eklemden tutularak her iki bacak uzatılır vertical olan muayenede anterior ve posterior tip luxation'larda uzunluğun' değişmediği yani heriki bacağında ayni uzunlukta olduğu görülür, fakat dorsal luxation da baçak kısalmış olarak görülür. Bacaklar caudal olarak uzatıldığı vakit (Şekil: 4) dorsảl luxationda bacakların uzunluğu ayni vaziyette olduğu halde anterior luxation'da arızalı bacağın boyu kısadır. Posterior luxation'da boyu uzar, intrapelvic Juxation'da bacak ayni uzunluktadır veya hafifçe her iki pozisyondada kısalmıştır (6).
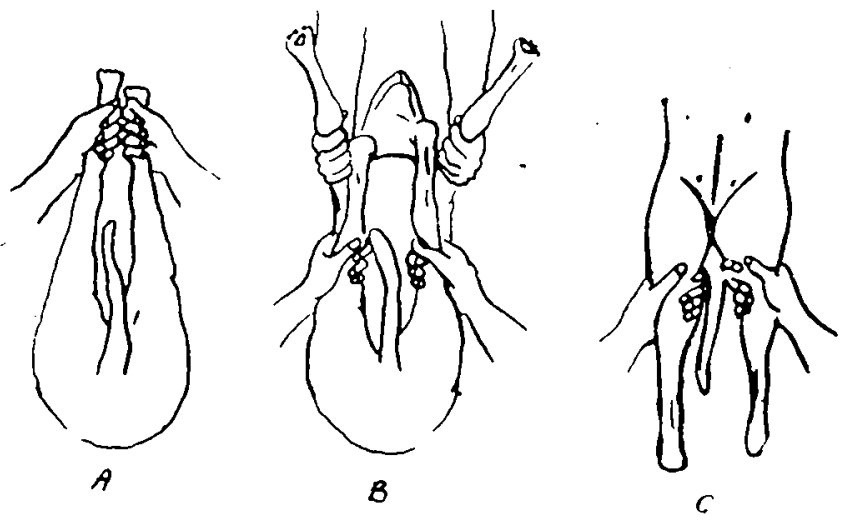

Sekil. 4 - Coxo-femoral luxation'da kullanılan basit muayene usulleri.

(A). Hastanın sırtüstiu yatırılmış pozisyonundaki vertical muayenesi,

(B). Ayni pozisyonda art bacakların öne doğru uzatılarak yapılan muayenesi.

(C). Ayni pozisyonda bacakların horizontal muayenesi. (Dollar'stan)

Mather, G. W. (1957), köpeklerde kalça çıkı̆ğı olaylarinda yürüyüş halinde sacro-iliac eklemde çok az bir hareketin bulunduğgunu bildirmekte ve aksiyal kısmın ve pelvis'in hareketsizliğine dikkati çekmektedir. Femur ve bacağın distal kısmı sagittal bir dïizlükte hareket ederler. Coxo- 
femoral eklem hayvan koştuğu vakit 110 derece hareket edebilir. Normal oturuş ve kalkış vardır ve herhangi fazla bir gayret sarfını icapettirmez. Oturan bir köpek normal olarak heriki ayağı üzerine tam istinatta bulunur(7).

Diagnose: Radyografik muayene ile kesinleşir. Fakat bu muayenede çok dikkatli olmalıdır. Bilhassa filim çekilirken hayvanın simetrik bir tarzda tutulması, önemlidir. Haỳvan tam pozisyonda olduğu vakit, ala

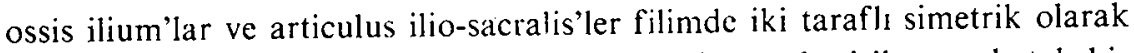
görünürler. Eğer Pelvis tam olarak kaset üzerine ycrleştirilmezse hatalı bir acetabulum görüntüsü eldc edilir. Radyografide cn uygun pozisyon, bacaklar arkaya doğru vücutla beraber ve yekdiğerine paralel olacak şekilde uzatılarak ventro-dorsal olarak çekiştir. Lateral pozisyonda Çekilen radyografilerden her zaman tam bir malumat alınmiyabilir $(3,6,10)$.

Prognose: Intrapelvic luxation hariç, iki gün içinde reddedilen vak'alarda prognose iyidir. Reddedilmiş veya sık sık luxation'un nüksettiği hallerde eklemin normal funksiyonunu yapamaması sebebiyle şüphelidir. Bazan bir pseudoarthrose şekillenerek funksiyoner şifa elde edilir, fakat bacağın şekli ve yürüyüş normal değildir.

Siyatik sinirin, posterior luxation'da basınca uğramasından veya açık bir ret ameliyesinden sonra N. Ischiadicus'un zedelendiği hallerde yavaş seyirli bir iyileşme beklenebilir. Acetabulum'un çevresinde şekillenen kırikla komplike hallerde caput femoris eklem yuvasında tam olarak tutulamiyacağından prognose süphelidir $(6,10)$.

Komplikasyonları: Kalça çıkığının sonucu, erken teşekkül eden sekunder, hipertrofik, dejeneratif arthritis gibi bozukluklardır. Bu değişimler 9-10 aylıkken görünmeğe başlar. Bu durumda mafsal aralığında nispetsizlikler ve kenarlarında yeni kemiksel teşekküllerle kendini gösterir. Mafsal aralığının subchondral yüzünde sclerose husule gelcbilir, ikinci latent tezahür ise, caput femoris'in şekil bozukluğudur ve bu subluxation'lu veya subluxation'suz olarak tczahür eder. Caput femoris ekseriya şeklini kaybeder, Proximal yüzünde düzlenir, caput femoris'in küçülmesi sebebiyle collum femoris kalınlaşmış görülür. Ekseriya caput femoris'ten daha kalındır. Collum femoris ayni zamanda kısalmış olarak dikkati çeker. Kalça çıkığı:

Kalça ekleminin tromatik dislocation'undan,

Acetabulum veya caput femoris'in kırığında,

Primer hipertrofik dejeneratif arthritis'ten,

Aseptik necrose (Osteochondritis) ten,

Pseudoluxation'dan ayırt edilmelidir (3. 12). 
Tedavi: Radikal tedavi, ret ve tespitten ibarettir. Büyük hayvanlarda ret gencl olarak imkânsızdır. Küçük hayvanlarda dahi eklemi çevreleyen dokularda husule gelen harabiyetten (yuvarlak ve capsular olan ligamentin kopması v.s. gibi) dolayı retention çoğu zaman çok zor hatta imkansız olur. Sığırlarda bir pseudoarthrose'un husulü maksadı karşılar,- bu suretle hayvan yürür, beslenir veya damızlık olarak servis yapabilir. Küçük hayvanlarda ise böyle bir yalancı eklem'in şekillenmesi maksada kâfi gelmez(10).

Coxo-femoral luxation'da ret, mümkün olduğu kadar erken yapılırsa başarılı olur. Mümkün olduğu taktirde genel anestezi ile kasların gevşemesi sağlanır ve hasta kontrol altında bulundurulmuş olur. Eğer ret kolay olursa hayvan anestezi altında iken röntgen ile kontrol edilmelidir. Hasta masaya yan vaziyctte, çıkık eklem üste gelecek şekilde yatırılır., sonra pelvis'in iধ tarafından geçirilen enli bir şeritle masaya tespit edilir. Geniş bir Thomas splint'i veya Gordon'un gericisi ile ret işi kolayca yapılabilir. Luxation anterior tarafa veya dorsal pozisyonda ise bacak articulus genu'nun altından kavranıp, ayni zamanda operatör diğcr elinin başparmağını acetabulum un altında, diğer parmakları trochanter üzerinde olacak şekilde yerleştirir, bacak abduction vaziyetine getirilir ve içeri doğru döndürülür, böylece os femoris'in anterior yüzü medial olarak uzanmış olur, bu vaziyette vak'alarin birçoğunda caput femoris, acetabulum'a femur'un boyun ve gövde kısmı anterior pozisyonda olmak şartiyle dorsal vaziyette gelir, bacağa çekme ameliyesi yaparak, diğer elle de caput femoris'i iterek çıkık reddedilmiş olur. Illk seferde başarı sağlanamazsa ameliye tekrarlanır.

Luxation, posterior olduğunda, ameliye bacağın dışa doğru çevrilip caput femoris'in anterior pozisyon alması hariç evvelkindekinin aynidir. Bu ameliyelerdeki gaye, caput femoris'i acetabulum civarına getirerek kolayca yerine koymaktır. Bazan caput femoris kolayca duyulabilen bir ses çıkararak yerine oturur. Bu kütleme sesi, eklemin yapı ve ligamentlerinde fazlaca hasarın husule gelmediğini bildirir ve tespit istemeksizin caput femoris yerinde lokalize olup kalır. Reddin sessiz olduğu vaziyetlerde caput femoris'in tekrar çıkması daima mümkindir. Ret yapıldıktan sonra kalça ve trochanter normal pozišyonlarını almalıdır. Her yöne doğru olan durumlarda bacakların uzunluğu eșit olmalıdır. Schroeder'e göre, kalça ekleminde şekillenen luxation'ların \%20 si nüksedici tabiattedir. Bazı hallerde ret, mutat manipulasyonlarla olmaz, bu hal ekseriya kasların,eklem kapsulası, lig. teres ve bazı vak'alarda da cartilago glcnoidale'nin zedelenmesinden ileri gelir. Retten sonra tekrar luxation şekillenirse kapalı metotlardan olmak şartiyle aşağıdakilerden herhangi biri tercih edilebilir:

Ehmer bacağı fleksiyon halinde tutan (unilateral veya bilateral bir metod tatbik etmektedir (Şekil. 5). 


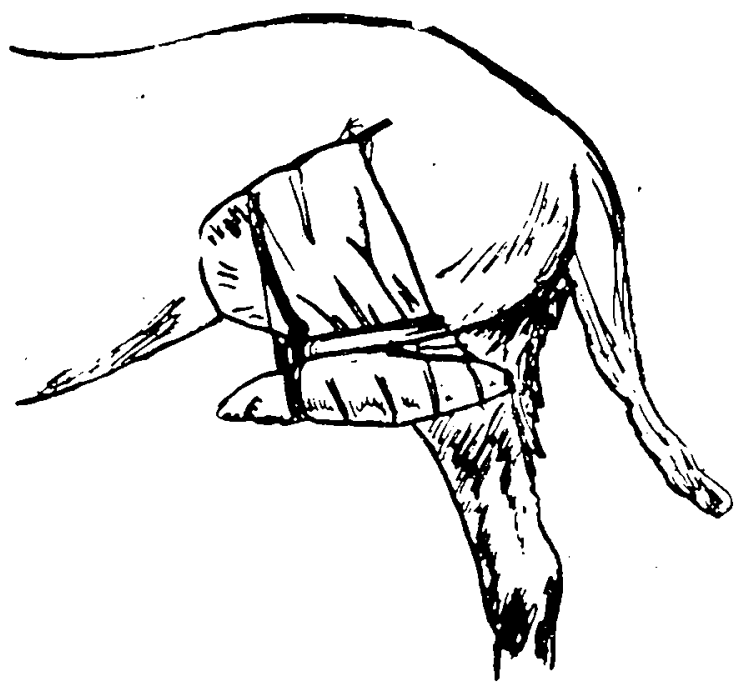

Şekil. 5 - Kaiça eklemi çıkı̆ı̣nda retten sonra, bacağın flexion halinde band la tespiti.

Schroeder ise thomas splinti'ni başarı ile kullanmaktadır

Stader yarım pin tatbiki ile eklemin tespiti hususunda ayrı bir metot tavsiye etmektedir.

De Vita, iki intramedullar pin ile caput femoris'in yerine tespitini bildirmiştir.

Yarbough, yukarıdaki metodu modifiye etmiş dik açı yapacak şekilde sokulan iki pin ile collum femoris'ten eklemin tespitinin daha muvafik olacağını bildirmiştir. $(6,10,12)$.

Garbutt, iki kalça çıkığı vak'asında metal vitallium vida, kullanarak açık operasyonla tesbiti yapmıș: ve her iki vak'adada başarılı sonuç almış$\operatorname{tir}(5)$.

\section{BÖLÜM 11.}

\section{A K'A L A R I M I Z}

Materyal ve metod: Materyalimizi kürsümüz kliniğine getirilen beş kedi ve on köpekte tespit edilen unilateral dislocatio articulus coxofemoralis'e ait onbeş vak'a teşkil etmektedir. Filhakika bu vak'aların dışında da birçok 
kalça eklemi çıkığı olaylariyle karşılaşılmıştır lakin bu vak'aların hemen hepsi üzerinde teferruatlı bir şekilde durulmuş klinik muayenede tespit edilen dislocation durumu, hemen ekserisinde radyografi ile teyit edilmiş ve sonra çoğunun hospitalizasyonu sağlanarak reddedilmiş ve hiç olmazsa biray sonraki durumları hakkında gereken bilgi edinilmiştir.

$\mathrm{Bu}$ onbeş vak'ada tedavi genel anestezi altında ve konservativ yolla sağlanmış ayrıca her vak'ada muhtemel nükslerin önüne geçmek maksadiyle yerlerinde izah edileceği veçhile bandajla tespit keyfiyeti sağlanmıştır.

Vak'a. 1- Dişi, alaca, puanter köpek, Prot. No. 2582. Birgündenberi topalladığından şikayetlc getirildi. Yapılan klinik muayenesinde, săg kalça ekleminde posterior tip bir luxation tespit edildi. Skopide görünüm, klinik diagnose'u teyit etti. Hasta hazırlandıktan sonra, genel anastezi altında bacağı (hasta bacak üstte olmak üzerc) yapılan traction, pression, rotation hareketleriyle çıkık reddedildi, skopi ile tekrar durum kontrol edilip nahiyeye ziftli bandaj kondu, Klinikte alıkonan hastanın ongün sonra yapılan kontrolünde kısalan ve asılı bir halde kalan bacağın normal uzunluğunu aldığı ve yürüyüşte evvelce görülen topallığın kaybolduğu görüldü. Hasta sahibine verildi. Yirmi beş gün sonra yapılan son kontrolünde herşey normal halinde bulunduğundan gezmesine müsaade edildi ve gönderildi.

Vak'a. 2- Yerli, alaca, crkck, köpck. Prot. No. 2621, üçgün evvel bir nakil vasıtası çarpması sonunda arka kısımında şekillenen hareketsizlikten şikâyetle getirildi. Yapılan klinik muayenede hem sağ pelvis kemiklerinde kırık ve hemde ayni tarafın kalça ek.leminde çıkık symptome’ları müşahede edildi. Radyografi ile klinik diagnose teyit edildi. Hasta diyete alınarak ertesi gün Nembutal ile anestezi jeneral altında evvela çıkık reddedildikten sonra kırık uçlarında skopi alında karşı karşıya gelmesi için çalışıldı ve sonra sacro-ilial bölgeye yeri hazırlanmış olduğundan ziftli bandaj kondu. Hasta onbir saat sonra anesteziden uyandı. Iztırabını inleme ile ifade ediyordu, biraz süt içirildi ve kas içi novaljin yapıldı. Ertesi gün pisleme ve işeme görülmediğinden sonda yardımiyle tahliye yapıldı ve gene süt ve bir miktarda kıyma verildi. Hastaya ayrıca hergün ıtırabını tahfif için luminalet tabletleri yutturuldu ve 600.000 u. D 3 vitamini enjeksiyonu yapıldı. sinkavit enjeksiyonlariyle muhtemel kanamaya mani olunmak istendi. Onbeş gün sonra defecation ve idrar yapma hali tabiiye döndü. Hasta ferahladı yiyeceğini kendisi istekle alıp yedi ve yerinde ayakta durabildi. Yirmi gün sonra bandaj alındı, yerine vitonal pomatı sürülerek sahibine verildi. Kırkbeş gün sonra yapılan kontrolde topallıkla, müterafık iyileşme hali tespit edildi (Topallı callus'ten ileri geliyordu). 


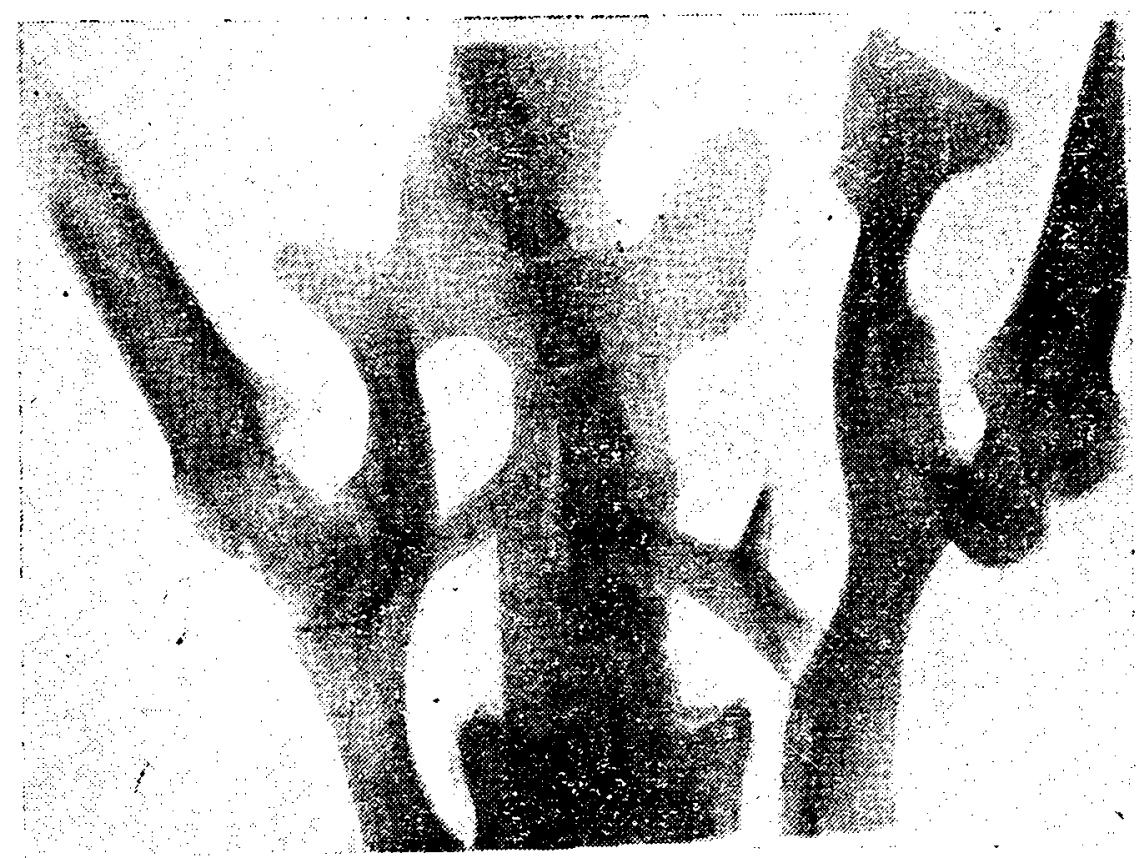

Şekil. 6- Vak’a 2 ye ait ret ve tespitten evvel fracture ile beraber kalça cklemi çıkı̆ının radyografik görünümü.

Vak'a. 3- Altı aylık, erkek, Ankara kedisi. Hayvanları Koruma Derneği Kliniğine getirildi. Düşme sonu sol art. coxo-femoraliste luxation bulundu, vaziyet A. Ủ. Vet. Fak. 1. Şirurji Kürsüsü röntgen'iyle teyit edildi.

Hayvan hazırlanmış ertesi gün Ether'le yapılas genel anestezi altında çıkık reddedilmiş ve ikinci vak'ada tarif edildiği şckilde, bunda da bacak fleksiyon tarzında sarılıp tespit edilmiştir. Iki gün sonra sahibi tarafından kedi gene aynı şikâyetle kliniğe getirilmiş, yapılan muayenede çıkığın yeniden şekillendiği anlaşılmış, ayrıca skopi altında durum teyit edilmiştir. Genel narkoz altında yeniden red ameliyesi icra edilmiş fakat bu sefer ilgili bölgeye, gereken hazırlık yapıldıktan sonra ziftli bandaj konmuştur. Genel anestezi de biraz uzun sürsün diye Nembutal kullanılmıştır. (İntraperitoneal). Bir haftalık klinik müşahedesinden sonra hayvan sahibine, gereken tenbihatla verilmiş, yirmi birinci gün kontrole getirildiğinde bandajin kendiliğinden kalktığı ve kıllarla asılı bulunduğu görülmüş kesilip alındıktan sonra yapılan yürüyüş kontrolünde normal hal tespit edilerek hayvan sahibine verilmiştir. 
Vak’a. 4- Beş yaşında, erkek tckir kedi, taksi çarpması sonu sağ articulus coxae'sinden şikâyetle Hayvanları Koruma Derneği'nin kliniğine getirilmiştir. Yapılan muayenede acetabulum'un kenarında hem kırık ve hemde aynı cklemde dislocation tespit edilmiş, A. Ü. Vet. Fak. I. Şirurji Kürsüsü Kliniğinde radyofgrafi ile durum tamamiyle açıklandıktadn sonra, hayvan hazırlanıp Nembutal ile genel anestezi altında red keyfiyeti sağlanmıs ve nahiycye ziftli bandaj konmuştur. Acetabulum'daki kırık parça çok küçük ve periostla asılı bulunduğundan ayrı bir ameliycye tevessül edilmemiş. Hayvanları Koruma Derneğinin kliniğinde hospitalize edilen bu hasta 21 inci gün bandajı alındıktan sonra normal olarak yürüdüğü anlaşılarak sahibine gercken tenbihatla teslim edilmiştir.

Vak’a. 5- İki yaşında; erkek; yerli, bcyaz köpek, Prot. No: 1608, üçgün evvel kayadan atlarken düşmüş ve ondan sonra topalladığından şikâyetle getirilmiştir. Muayenesinde, sağ art baca ğın sol bacaktan 1,5 santimetre kadar kısa olduğu ve coxa-femoral bölgenin ağrılı bir şişlikle çevrelendiği tespit edildi. Pelvis radyografisinde, sağ anterior coxo-femoral luxation bulunduğu- anlaşıldı. Hazırlandı, ertesi gün Nembutal ile anesteziye edildi, yapılan çekme, germe, ve döndürme hareketleriyle ve kütleme sesi işitilerek ret ameliyesi yapılmış ve sonra ilgili nahiye üzerine ziftli bandaj konmuştur. Birhafta sonra bandaj alınmış ve hayvanın yeniden yapılan radyografisinde eklemin normal durumunu muhafaza ettiği anlaşılmış, hasta evinde gerekli kontrol altında kalmak şartiyle taburcu edilmiştir. Biray sonra kontrolünde nüksün olmadığ 1 ve gene eskisi gibi normal hareketlerini yaptığı görülmüştür.

Vak’a. 6- Birbuçuk yaşında, erkek, Seter köpek, birhafta evvel bir av partisinde otomobil çarpışması sonu sağ arka bacağından topalladığından şikâyetle Ankara Veteriner Md. lüğü kliniğine götürülmüş, orada friksiyon ve istirahat verilerek evine gönderilmiş, sonra yapılan tedaviye rağmen iyileşme görülmediğinden bahisle Hayvanları Koruma Derneği Kliniğine getirilmiştir. Ayakta ve yürüterek yapılan muayeńede sağ bacağın uzunluğunun diğerinden daha kısa bulunduğu trochanter çıkıntısının mukabiline nazarán pek mütebariz olduğu farkedilmiş, hasta A. Ü. Vet. Fak. I. Şirurji Kürsüsü Kliniğinde radyografik muayeneye tabi tutularak sağ anterior ve dorsal bir coxo-femoral dislocation'u tespit edilmiştir. Hazırlandıktan sonra Nembutal ile genel anestezi altında yapılan ret ameliyelerinden sonuç alınmadığından eklem üzcrinde deri traş edilip dezenfekte edildikten sonra vertikal 3,5 sm. uzunluğunda deri altındaki kaslara bir ensizyon yapılmış bir elin baş parmağı ile rectal yolla diğer elin parmağıylede ensizyon yarasından trochanter üzerine yapılan basınç ve bacağa yaptırı- 
lan çekme ve rotation hareketleri sonunda ret ameliyesi güçlükle yapılabilmiştir. Sonra ensizyon yarası steril şartlar altında dikilmiş ve yalnız dikiş hattı dışarda kalmak üzere bölge üzerine ziftli bandaj konulmuştur. Onyedi günlük tam bir istirahatten sonra bandaj kaldırılmış, yara tamamen iyileşmiş ve yapılan radyografide eklemin normal pozisyonda bulunduğu bacağın basışa diğer bacak gibi iştirak ettiği anlaşıldığından onbeşgün kadar daha istirahat verilerek tedavisine son verilmiştir (Şekil - 7 ve 8).

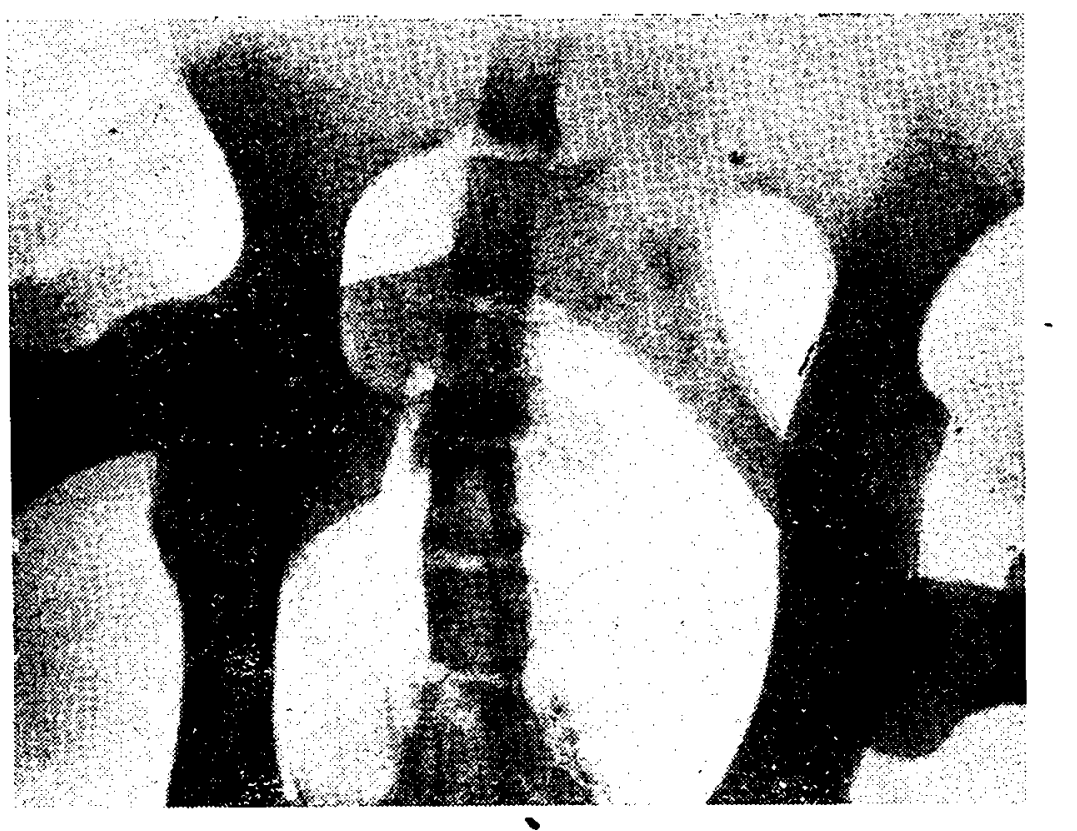

Şekil. 7- Vak`a 6 ya ait ventro-dorsal görünüm (Ret ve tespitten evvel)

Vak’a. 7--. Üçbuçuk yaşında, yerli, dişi, köpek, Prot. No. 2208, iki saat evvel sopa ile vurulma sonu sol bacağından şikâyetle getirildi. Yapılan klinik muayenesinde; bacağın geriye doğru gergin ve mukabilindeki bacaktan oldukça kısa kaldığı görüldü olayın bir kalça çıkığı'nı gösterdiği anlaşld. Nembutal'ile genel ancstezi altında çıkıkların reddinde duyulabilen tipik kütleme sesi ile red ameliyesi yapıldı ve sonra bacağı tam fleksiyon halinde bir band tatbik edildi. Iki haftalık bir kontrolden sonra normal yürüyüş, oturtup, kalkış yapabildiğinden Sahibine iade edildi.

Vak’a. 8- Hayvanları Koruma Derneğine ait, beş yaşında, yerli siyah köpek. Eski üyelerinin ifadesine göre bu köpek bir aylıkken sokaktan 
alınmış ve o zamandanberi arka sol becağında anormal bir bası̧ hali müşahede edildiği bildirilmiştir. Yapılan muayenede sol bacağın azçok içe dönük vc mukabil bacaktan bir santim kadar kısa olduğu kalça eklemi çıkıntılarında diğerine nazaran trochanter femur'un daha değişik ve mütebariz bir yer işgal ettiği tespit edildi. Vak'anın bir kalça eklemi subluxation'u veya luxation'u olabileceği düşünülerck bir kerrede radyolojik muayene ile duru mun tespiti cihetine gidildi. Genel anestczi altında bir beşeri röntgen servisinde yaptırılan (grafilerde adı geçen eklemde anterior ve dorsal luxation

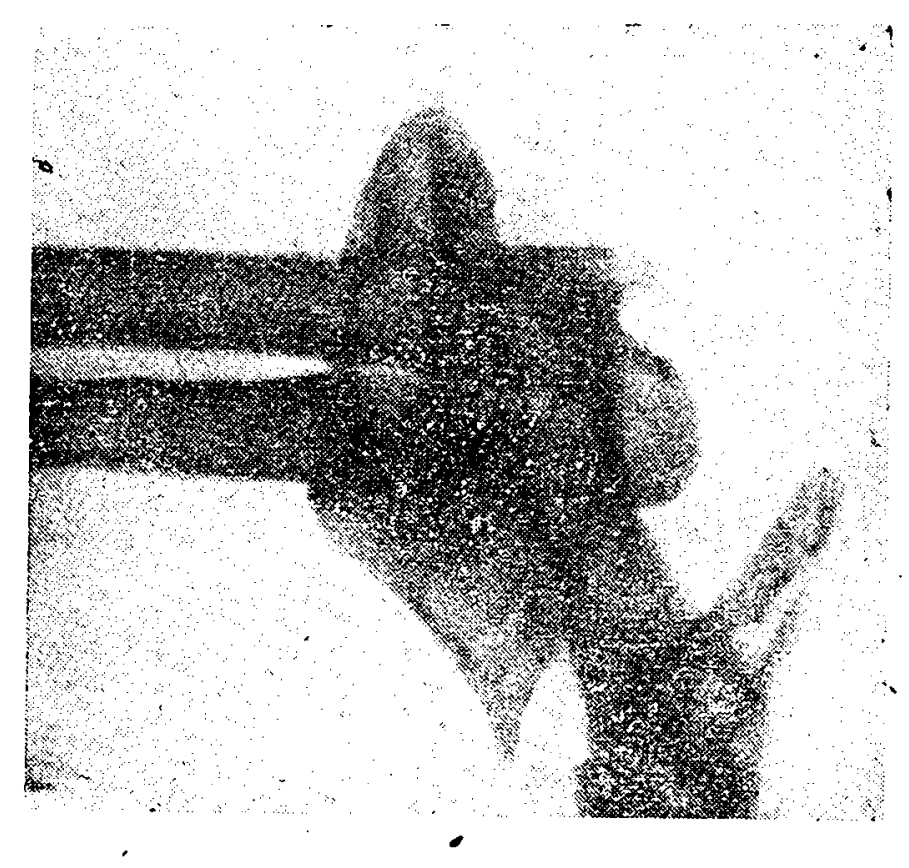

Şzkil. 8 - Vak’a 6. nın lateral pozisyondaki radyografik görünümü.

bulunduğu anlaşıldı. Genel anestezi altında mutad maniplasyonlarla kalça eklcminin yerleştirilmesine çalışıldıysada başarı sağlanamadı, üç gün sonra altıncı vak'ada olduğu gibi genel anestczi altında (Nembutalle) luxation'un lokalize olduğu eklem üzerinde yaplan ensizyonla, rectal yollada yardıncı manevralar yapılmak üzere caput femoris acetabulum hizasına kadar çekilip oturtuldu, yara dikildi civarına ziftli bandaj kondu, hastaya fazla hareket etmemesi için günlük dozlarin yarısı nispetinde Luminalet tabletleri yutturuldu, sckizinci gün dikişler alındı, onsckizinci gün bandaj kaldırıldı, yürümenin normale yakın olduğu ve bacak uzunluğunun mukabiline müsavi bulunduğu görüldü evvelce yapılan radyografi pozisyonunda yeni bir rad- 
yolojik muayene yapıldı, operasyon gören eklemde şok hafif derecede bir subluxation hali tespit edildi, başka bir müdahele yapılmaksızın hayvan serbest bırakildı (Şekil: 9).

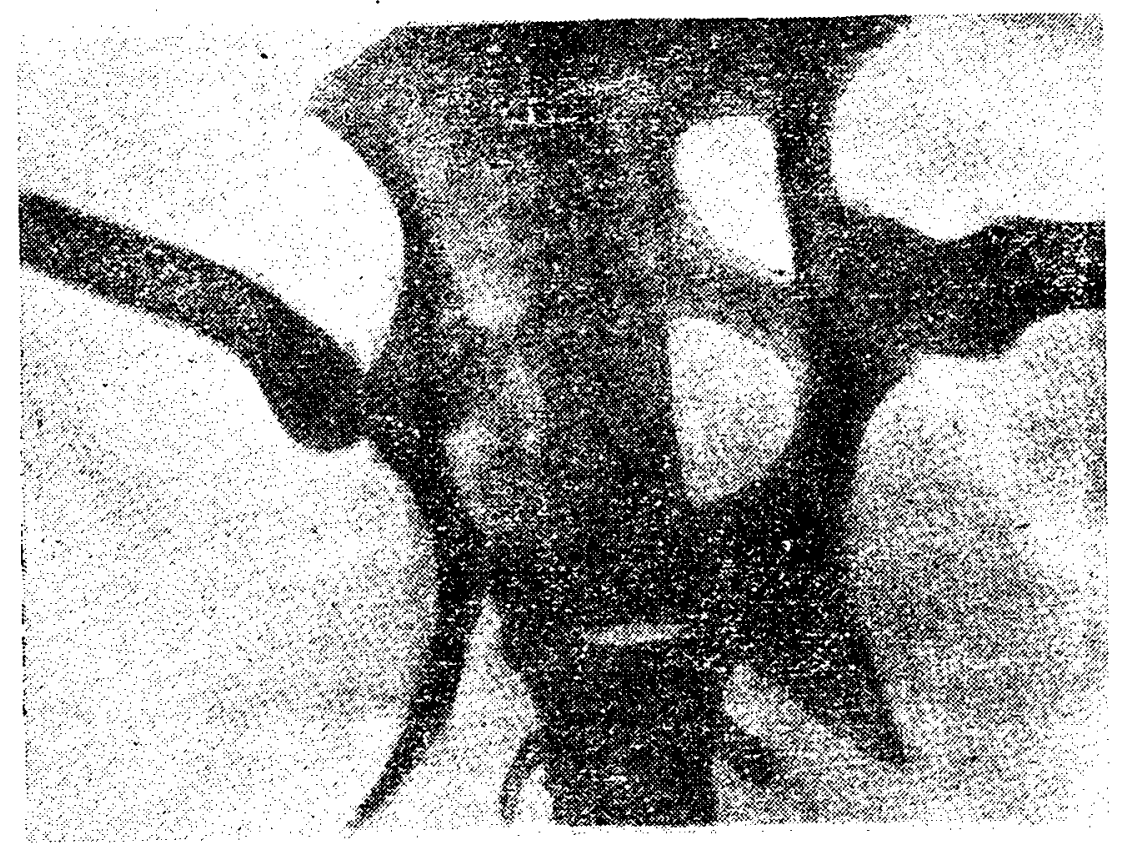

Sckil. 9- Vak'a 8 e ait ret ve tespitten svvelki röntgen görünümü.

Vak'a. 9, 10, 11- Altı yaşında, yerli beyaz fino Prot. No. 2156, üç yaşında, dişi seter köpek, Prot. No. 1709. Beş yaşında, yerli, crkek köpek, Prot. No. 798.

Birincisi, ikigün evvel araba çarpması sonu arka tarafından topalladığından şikâyetle, ikincisi bir gün evvel av partisinde otomobilden atlarken kalça, kısmı üzerine yiyecek sandığını devirmck surctiyle topalladığından, üçüncï vak'ada dört gün evvel evden kaçmış olarak sokak kapısinda çamurlara belenmiş halde arkasında sakatlık bulunduğu şikâyetiyle kliniğe getirilmişlerdi.

Yapılan klinik muayénede; dokuzuncu vak'ada bacak uzunluğunda herhangi belli bir fark olmamakla baraber sol kalça ckleminde topallığa sebcbiyet veren bir hassasiyetin bulunduğu görülmüş, skopide subluxation'a benzer bir görünüm tespit edildiğinden, grafisi yapılmış ve adı geçen eklemde tam bir subluxation müşahede edilmiştir. 
10 uncu vak’ada sol bacağın sağa nazaran içe dönük ve kısa olduğu harekete iştirak etmediği ve hatta yere basmadığı klinikman görüldükten sonra yapilan grafide sol kalça ekleminde anterior pozisyonda bir luxation bulunmuştur.

11 No. lu vak'ada ise benzeri muayeneler yapıldıktan sonra sağ kalça ekleminde antero-dorsal pozisyonda bir luxation tespit edilmiştir.

Dokuzuncu ve onbirinci vak'alar Nembutal ile genel anestezi altında red ameliyesi yapıldıktan sonra ziftli bandaja alınarak sağıtılmıs, onuncu vak'ada ise anestezi altında luxation reddedildikten sonra baçak tam bir fleksiyon halinde bandlarla sarılıp tespit edilmiş ve grafi ile yeniden durumu kontrol edildikten sonra' gercken tedbirleri alması tenbih edilerek sahjbine verilmiştir. onbirinci gün yeniden yapılan kontrolde köpeğin bacağını normal olarak kullandığ yapılan muayene ile anlaşılmış, bandaj kaldırıldıktan sonra bir hafta süre ile oda içinde serbest bırakılması kararlaştırılmıştır. Bir ay sonra geldiğinde hareket funksiyonlarının tamamen normal cereyan ettiği görülmüş ve serbest bırakılmıştır.

Vak'a. 12, 13 ve 14- Üc yaşında, yerli, sarı kedi, Prot . No. 384. 4 yaşında, yerli, Ankara Kedisi, Prot. No. 2727. İkibuçuk yaşında, beyaz Ankara Kedisi, Prot. No. 2960 İlk ikisinde arka tarafın kapı arasında sıkışması sonu şekillenen bir topallık, üçüncüsünde ise sopa ile vurma sonu arka tarafta bulunduğu bildirilen bir topallıkla getirildiler.

Yapılan klinik ve radyolojik muayenelerde, 13 üncü vak'ada sağ kalça ckleminde anterior bir dislocation, 14 üncii vak'ada gene sağ articulus coxae'de anterior olarak şekillenen luxation, 13 üncü vak'ada ise her iki art bacă̆ın yanlara doğru tamamiyle irtibatsız bir durumdaymış gibi açılıp kapandığı ve trochanter'lerin her iki tarafta da ele geldiği acetabulum'un boş olarak geride kaldığı tespit edilmiş, durumu röntgen cihasının işlememesi sebebiyle radyolojik olarak teyit edilememiştir. Bu sonki vak'aya her iki kalça ckleminde antcrior pozisyonda luxation diagnose'u ikame edilmiş̧îr.

Her üç vak'ada da eterle genel anestezi sağlandıktan sonra red keyfiyeti sağlanmış ve sonra nahiye tespit maksadiyle konan ziftli bandajlarla hareketsiz hale getirilmiştir. 13 ve 14 üncü vakalar onbeş günde iyileşmiştir.

Onikinci vak'ada kabızlık ve işiyememe hali hemen başlamış fakat her gün yapılan masaj ve lavmanlarla tahliye ikmkânı sağlanmış onyedigün sonra alttaki kılların uzamasiyle her iki kalçayı içine alacak şekilde konan ziftli bandaj gene eter narkozu altında kesilip çıkarılmış, kedinin arka bacakları üzerine durubildiği görülmekle bir haftalık kat’i istirahat verilmiştir. Bir hafta sonunda oda içinde yürüme kontrolleri yaptırılmış, azçok bir güçlük 
olmakla beraber, normale yakın şekilde kedinin yürüyebildiği görülmüş ve taburcu edilmiştir.

Vak'a. 15- Dokuz yaşında, yerli, siyah-beyaz alaca köpek. Prot. No: 2280. İki gün evvel merdivenden atlama esnasında şekillendiği bildirilen arka kısımlara münhasır bir topallıktan şikâyetle getirilmiştir.

Yapılan klinik muayenede; sağ kalça eklemindeki girinti ve çıkıntıların mukabiline nazaran değişik olduğu görülmüş, bacağın uzunluğunda kısalma ve basışta yere istinat etmeme kaydedilmiştir. Bir kalça eklemi luxation'u şüphesiyle, kesin diagnose için radyolojik muayeneye sevkedilmiş burada da adı geçen kalça ekleminde luxation (anterior) bulunmuştur. (Şekil. 10).

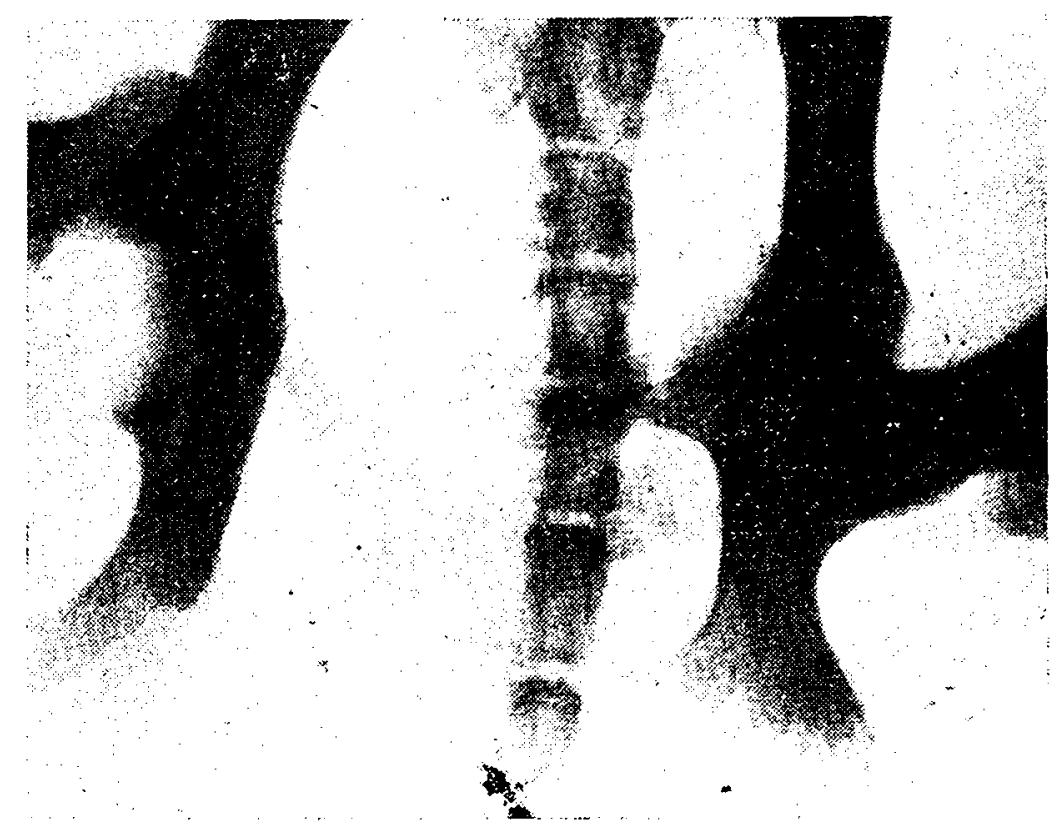

Şekil. 10-Vak'a $15 \mathrm{c}$ nin ret ve tespitten evvelki durumu.

Anestezi general altında diştan yapılan çekme, germe ve döndürme hareketleriyle mafsal yerine oturtulmuş ve tespit için ziftli bandaj konmuştur Onsekizinci gün bandaj alınmış, köpeğin normal olarak bacağını hareket ettirdiği görülmekle tedavisine son verilmiştir. 
VAK'ALARIMIZIN TOPLU OLARAK CETVELLE IFADESI

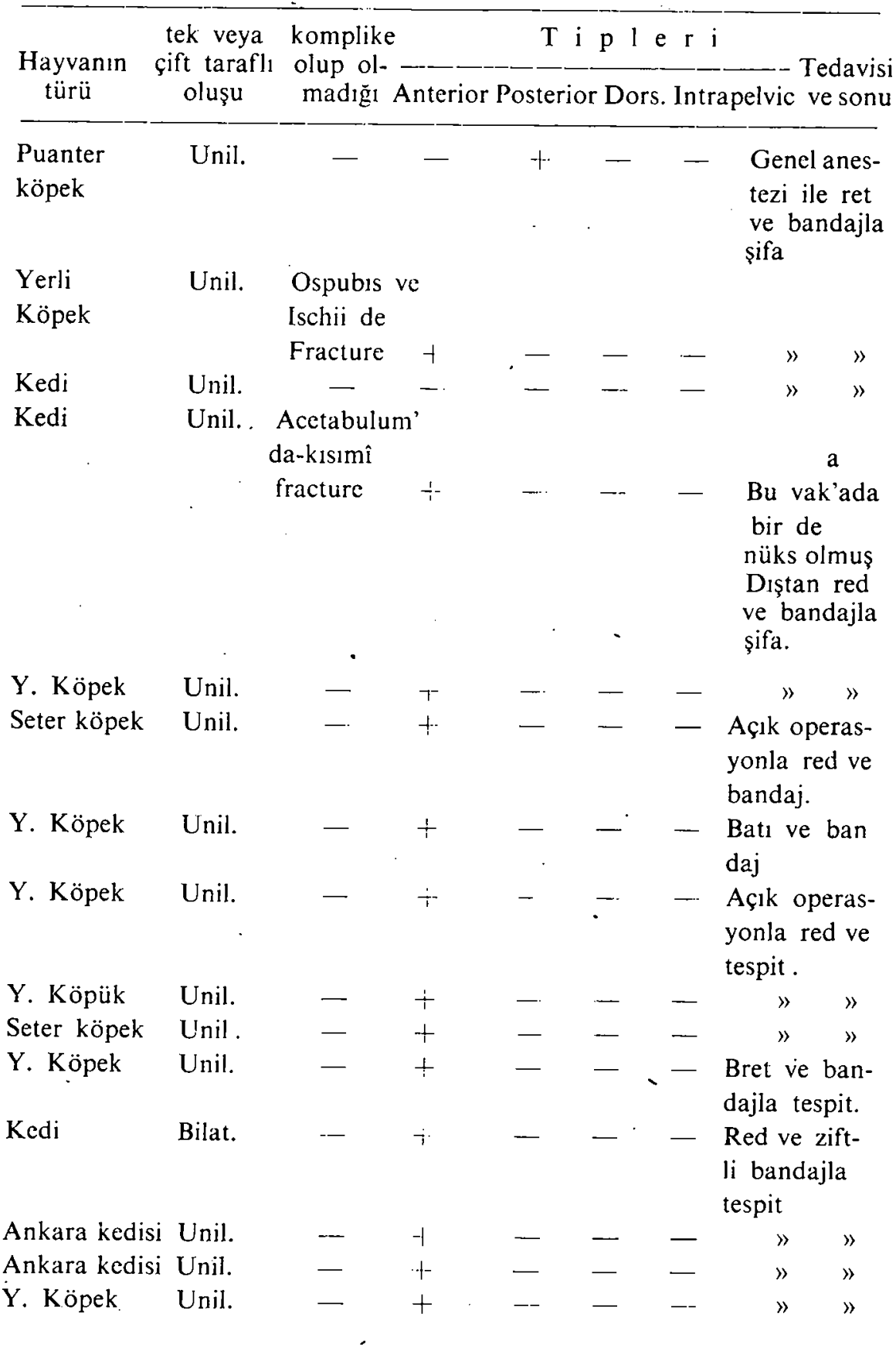




\section{Karşılaştırma ve sonuç}

Etyoloji yönünden kalça çıkıkları hemen büyük çoğunlukla tromatik sebeplerin tesiri altında ફ̧ckillenmekte ve bu sebeplerin başında da, nakil vasıtalarının lateral yönden çarpmaları gelmektedir.

Bizim vak'alarımızda etkiyen tromatik faktörler sırasiyle:

Beş vak'a nakil vasıttası çarpması sonu,

Üç vak’a yüksek yerden atlama esnasında,

Uç vak'a yan taraftan sopa ile vurma sonunda,

iki vak'a düşüp bir ağılık alunda kalma sonu

Bir vak'a kapı arasında sıkışma sonunda (Bilateral), ve

Bir vak'a da sebep belli olmaksızm getirilmiştir.

Vak'alardan beşi kedi, onu köpektir. Yalnız vak’alardan ikisinde kalça eklemindeki luxation, ile acetabulum'un kenarında ve Ospubis ile ischii'de de şekillenen kırıkla komplike bulunmuştur.

Kapı arasında sıkışmak suretiyle şekillenen diğer bir kediye ait olayda da luxation bilateral olarak şekillenmiştir.

Vak'alarımızda klinik muayene ve radyolojik kontroller'de tespit ettiğimiz luxation tipleri şöyledir:

14 vak'ada anterior,

1 vak'ada posterior.

Anterior çıkık liplerinin büyük bir kısmında ayni zamanda dorsal pozisyonda müșahede edilmiştir. Yukarıdaki nispetlerle ilgili durum, klasik kitaplardakilere identiktir.

Symtome olarak, ventro-dorsal pozisyonda, hastanın arka bacaklarınin kavram kısmı bir muayene masasının kenarına gelecek şekilde tutuldukta, muayeneyi yapan operatörün ellerinin baş parmakları her iki Art. coxo-femoralis üzerinde, diğer parmaklarla regio femoralis dış, ön ve içten kavrandığında, trochanter'in anterior vak'alarda çok belirli bir hal aldığı, tirçok halde acetabulum'daki boşluğun hissedildiği ve bacağın bazı hallerde rotation'a màruz kaldığı, anterior çıkık ekleme ait bacağın boyunda diğerine nazaran enaz bir santim kadar kısalma bulunduğu tespit edilmiş yalnız posterior olarak şekillenen vak'ada arızalı bacağın uzunluğunun diğer normal bacağa nazaran iki santimetre kadar uzadığı müşahede edil miştir. Bu karşılaştırma ve ölçmede ayrıca hayvanın sırtüstü sịmetrik bir şekilde yatırıldıktan sonra arka bacakların dik bir tarzda uzatılarak yapılan muayene şeklinde kullanılmıştır. 
Bizde, kalça çıkığı vak'alarında hayvanın evvela masa üzerinde ventrodorsal ve sonra sırtüstü vaziyette bacakların ilgili eklem kısımlarında muayenenin yapılmasını ve bu suretle girinti ve çıkıntılardaki farklar tespit edildikteñ sonra, baćă̆ın uzunluğunda farkın bulunup bulunmadığının ölçülmesini, ve nihayet imkânlar elverirse anestezi general altında yoksa anestezisiz ve fakat dorso-ventral ve tam simetrik şekilde her iki kalça ekleminin radyografisinin yapılmasının kesin diagnose koymada en emin ve kesin yol olduğunu burada açıklamak isteriz Vak'alarımızın birinde yaptığımız üç radyografiden ilk ikisinde titizliği sebebiyle köpeğin teprenip simetriyi bozduğundan dolayı tipik anterior luxation durumu hususunda hiçbir ipucu vermemiştir.

Biz vak'alarımızda diagnose'u kcsinleştirmek için imkânlarımız nispetinde radyoskopi ve radyografiye yer verdik.

Tedavi hususunda, genel olarak anesthesie generale altında ve yan yatmış vaziyette traction, extention, rotation ve pression gibi hareketlerle çıkığın reddini sağlamaya çalıştık, bazı olaylarda rectal yolla palpationdan da faydalandık. Vak'alardan ikisinde dıştan red kâbil olmadığından çıkık eklem üzerinde gerekli tedbirlere riayet edip, tekniğine uyǵun yapılan ensizyonlarla deri ve kaslar ayırt edilmiş ve sonra caput femoris daha kolay bir şekilde yerine oturtulmuştur. Sonra yara dikilerek tedavi edilmiştir. Bir vak'ada nüks görülmüş, tekrar reddedilip tespit edilmiştir Biz tespit için ziftli bandajı kullandık ve çok başarılı sonuç aldık Bazı çok yeni (birkaç saatlik) vak'alarda reḍden sonra bacağın genu ekleminden tam flexion halinde bandlarla tespiti sağlanmıştır.

Kırıkla komplike ve bilateral luxation'lara ait üç vak'ada iyileşmeden sonra hafif bir topallık kalmıştır. Diğer vak'alarda sonuçlar tam başarılı olmuştur.

VAK'ALARIMIZIN CETVEL HALINDE TOPLUCA IFADESİ

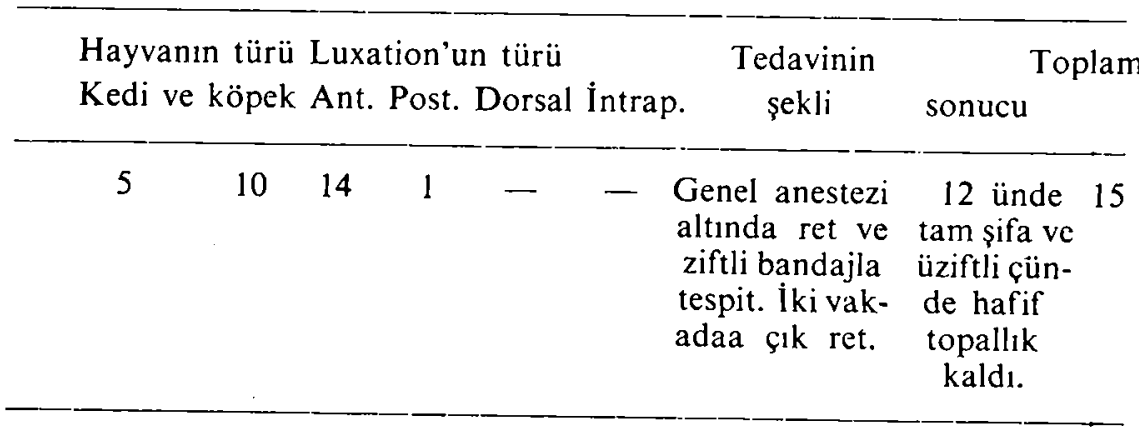




\section{SUMMARY}

Dislocation of coxo-femoral articulation in dog ānd cat.

In this paper 15 cases of hıp dislocation in cats and dogs ( 5 cats and 10 dogs) are discussed.

The causes of this lesion is commonly the result of a severe contusion by a kick, jump, blow or fall, or passage of a wheel of vehicle over the region.

Two cases are complicated with the fracture of acetabulum or os pubis and 1schii, one other case was a bilateral luxation which happened after the subject was pressed between the door and the door case.

14 cases were anterior (Precotyloid) and, 1 case posterior (postcotyloid) type of dislocation.

Dorsal situation of caput femoris was observed in the former type The diagnosis was confirmed by radiological examination, and ventro-dorsal view was found sufficient.

The symptomes were lameness, deformation of the region at the standing position. The length of legs were compared and palpation of trochanter was made under the influence of generale anesthesia.

The signs of anterior luxation were: elevation and rotation outward of trochanter, length of the affected leg was found shorter horizontally (0,5-1,5 sm.), the affected leg does not beare body. In one case (posterior) rotation of the leg was observed inward, trochanter was found the same as anterior luxation the leg lengthened horizontally $(2 \mathrm{sm}$.).

The treatment was completed with the following four steps:

(a) Prepartion of patient,

(b) Administration of generalc anesthesic drug (mostly Nembutal for dogs and Ether for cats);

(c) Reduction of coxo-femoral luxation by some manipulations (such as tractión, adduction, rotation and pression);

(d) fixation of hip joint by a bandage (mostly black pitch).

The reduction was very easy and a soundness was heàrd in recent cases where the patient were bought to the clinic in a few hours. The reduction were made by uncision on the affected region in two old standing cases. A recurs was observed in one case.

The results of treatment were satisfactory; in 12 cases tcrminated complet recovery, a slight lameness remained in three cases. 


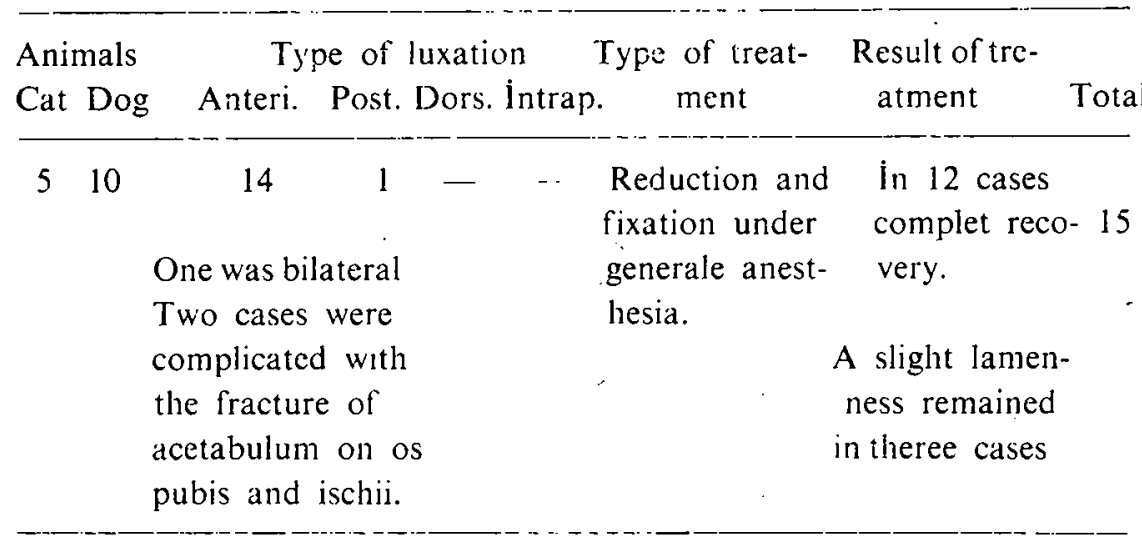

Not: Şekillerin hazırlanmasında yardımı olan Vet. Hek. N. İplikçioğluna teşekkür etmeyi borç biliriz.

\section{LITERATÜR}

1- Berker, S. Z. (1940): Ehli Hayvanlarm Cerrahi Hastallklart. DersKitabı Cilt. 2, Sahife: 23-24, Y. Z. E. Ankara.

2- Berker, S. Z., Öktem, B. (1956): Genel Sirurji, Ders kitabı, Sahife: 369-374, Yeni Desen Matbaası, Ankara.

3-Carlson, D. W. (1961): Veterinary radiology. P. 330-335. Lca and Febiger, Philadelphia.

4- Dilgimen, H., Doğuer, S., Erençin, Z. (1946): Karşılaştırmalt anatomi'den osteologie. Cilt. 1, Sahife: 173-175, Y. Z. E. Ankara.

5- Garbutt, R. J. 1958): Animal bone surlgery. Dislocation of Hıp. J. A. Vet. Med. Ass., vol. CXIII, 857: 144-150.

6- Leonard, P. K. (1961): Orthopedic surgery of the dog and cat. p. 191207 W. B. Saunders Commp. Philadelphia and London.

7- Mather, G. W. (1957): Common hip problems in the dogs. The North Am. Vet. v. 38, 10: 306-312.

8-- Mayer, K., Lacroix, V. J., Hoskins, P. H. (1957): Canine surgery. p. 757-767, Am. Vet. Pub. Inc; Santa Barbara California.

9-- Milier, W. C., West, G. P. (1959): Black's veterinary dictionary. p. 459, Adam and Charles Black, London.

10-- O'Connor, J. J. (1952): Dollar's veterinary surgery. p. 855-857. Bailliere Tindall and Cox. London. 
11- Sisson, S. (1958): The anatomy of the domestic animals. P; 233-234. W. B. Saunders Comp. Philadelphia and London.

12- Shuttleworth, A. C., Smythe, R. H. (1960): Clinical veterinary surgery. v. 2., p. 384-387). Crosby, Lock Wood and Son LTD. London. 